\title{
O INTERNATO ESCOLAR "O ATENEU”: PRODUÇÃo DE SUBJETIVIDADE NA INSTITUIÇÃO TOTAL ${ }^{1}$
}

\author{
Sílvio José Benelli ${ }^{2}$ \\ Faculdade de Ciências e Letras, UNESP, Assis, SP
}

\begin{abstract}
Neste artigo, procuramos detectar os efeitos da institucionalização na produção de subjetividade num estabelecimento escolar totalitário. $O$ campo de pesquisa é o romance "O Ateneu”, de Raul Pompéia, analisado a partir da teoria de Goffman (1961/1987), relativa às instituições totais. Procuramos descrever a carreira moral que o personagem Sérgio desenvolve ao ingressar no internato, mapeando as vicissitudes pelas quais passa no contexto institucional: período de adaptação, crises evolutivas, iniciação sexual, problemas de rivalidade fraterna etc. Os estabelecimentos totais parecem se organizar de maneira característica e funcionar de modo autônomo. Somente poderemos compreender os problemas sociais e os efeitos na subjetividade produzidos pelas instituições totais, por meio do estudo das relações de poder subjacentes a esses estabelecimentos. O lapso de tempo no qual o indivíduo vive como internado pode deixar marcas profundas na sua subjetividade e se configura como um tema de estudo apropriado em si mesmo.
\end{abstract}

Descritores: Subjetividade. Análise institucional. Internato. Educação.

1 Este artigo é parte da pesquisa de mestrado intitulada Pescadores de Homens: A Produção da Subjetividade no Contexto Institucional de um Seminário Católico, que está sendo desenvolvida por Sílvio José Benelli, sob orientação de Abílio da Costa-Rosa, Professor Assistente Doutor junto ao Departamento de Psicologia Clínica e do Curso de Pós Graduação em Psicologia - Faculdade de Ciências e Letras, UNESP, Assis, SP, com financiamento da FAPESP.

2 Endereço para correspondência: R. José Bonifácio, 1185, Apto. 41B. Jd. Cristo Rei. Marília. CEP 17513-230. Fone: (14) 422-5040. Endereço eletrônico: sjbewelli@yahoo.com.br 


\section{As instituições totais na sociedade contemporânea}

W este artigo, realizamos uma análise institucional do internato escolar, Ateneu". O instrumento de análise utilizado baseia-se na teoria de Goffman (1961/1987) sobre as instituições totais. A condição de internado, seja num hospital geral, num hospital psiquiátrico, numa prisão, num colégio, num convento ou num seminário, parece-nos relevante em si mesma como um assunto que merece ser estudado e compreendido (Guirado, 1987). A estratégia da internação visando a distintos objetivos continua muito presente em nossa sociedade atual.

Segundo Goffman (1961/1987), as instituições totais se caracterizam por serem estabelecimentos fechados que funcionam em regime de internação, onde um grupo relativamente numeroso de internados vive em tempo integral. A instituição funciona como local de residência, trabalho, lazer e espaço de alguma atividade específica, que pode ser terapêutica, correcional, educativa etc. Normalmente há uma equipe dirigente que exerce o gerenciamento administrativo da vida na instituição.

Acreditamos que as instituições totalitárias não desapareceram na sociedade contemporânea. Pelo contrário, há uma florescente indústria funcionando ativamente no sistema prisional (Salla, 2000), nos novos pavilhões construídos para a FEBEM (Guirado, 1986) e nos inúmeros presídios que se espalham pelo interior do Estado de São Paulo. Nesta categoria de instituições, ainda entram os hospitais psiquiátricos (Castel, 1978; Foucault, 1972/1999a; Goffman, 1961/1987; Levinson \& Gallagher, 1964/1971), internatos escolares em geral (Benelli, 2002; Hesse, 1970, 1980; Lautréamont, 1986; Musil, 1986; Perrone-Moisés, 1988; Pompéia, 1888/1997; Rego, 1933/1979), colégios agrícolas com internato, asilos para idosos, orfanatos para crianças, quartéis e casernas militares, escolas para formação de policiais militares (Cruz, 1989), seminários católicos que acolhem adolescentes e jovens universitários em regime de internato para prepará-los para o sacerdócio (Benelli \& Costa-Rosa, 2002; Cabras, 1982; Ferraz e Ferraz, 1994; 
Rocha, 1991; Tagliavini, 1990; Trevisan, 1985), plataformas petrolíferas marinhas, casas que acolhem crianças em situação de risco, o exército etc.

O modo de recrutamento varia nas instituições totais. Os novatos ingressam com diferentes estados de ânimo. O espectro vai do absolutamente voluntário, passa pelo semivoluntário, até o involuntário. Como exemplo do recrutamento voluntário, temos as instituições religiosas, nas quais os indivíduos ingressam por livre e espontânea vontade. Esses estabelecimentos lidam apenas com aqueles que se consideram chamados, escolhendo entre eles os que os dirigentes julgam mais adequados e sérios em suas intenções. Nesse último caso, a conversão já parece ter ocorrido e a tarefa se resume apenas em indicar ao novato (aspirante, noviço, seminarista) as maneiras pelas quais pode atingir autodisciplina.

O exército representa um tipo de instituição na qual o recrutamento pode ser considerado semivoluntário: os internados são obrigados a servir e têm muitas oportunidades para compreender que esse trabalho é justificável e pode ser exigido em função de seus interesses finais.

Entradas inteiramente involuntárias podem se dar nos casos de internação num hospital psiquiátrico, reclusão na prisão, incorporação forçada à tripulação de um navio. Neste último caso, os internados oferecem maior resistência ao perfil que a equipe dirigente quer lhes impingir.

A permeabilidade à influência da sociedade-ambiente nos padrões sociais institucionais também varia de modo diverso. Quanto maior o grau de influência mútua entre a instituição e a sociedade, mais suas diferenças se reduzem.

$\mathrm{Na}$ análise do processo de admissão nas instituições totais, os aspectos impermeáveis do estabelecimento se realçam. O novato sofre um processo de despojamento e nivelamento no seu ingresso, perdendo as várias distinções sociais que possui na sociedade mais ampla: idade, riqueza, status social, diferenças de idade, inclusive o nome em certos casos etc. Um certo nível de impermeabilidade parece ser necessário para a manutenção do moral e da estabilidade da instituição. Paradoxalmente, ao suprimirem as distinções sociais externamente válidas, as instituições totais mais radicais podem ser 
também as mais democráticas. Elas, porém, precisarão empregar necessariamente algumas distinções sociais já estabelecidas na sociedade mais ampla, ainda que isso ocorra apenas para realizar as tarefas indispensáveis relativas à sociedade e ser por ela tolerada.

A instituição total é um híbrido social, constituído parcialmente como grupo residencial e também como organização formal. Ela é um viveiro ou uma estufa que funciona como instrumento para modelar, mudar e transformar pessoas. Cada instituição total é, assim, um experimento natural do que se pode fazer com a identidade de um indivíduo. É aí que reside seu interesse para a Psicologia que se ocupa com o estudo da Subjetividade e Saúde Coletiva.

Tomando o romance de Raul Pompéia como campo de análise, podemos acompanhar o menino Sérgio e seu mergulho no mundo institucional do internato escolar e verificar a presença e ação dos vários mecanismos que as instituições totais fazem funcionar com a finalidade de controlar e modelar e produzir o indivíduo. Pompéia descreve à saciedade a "carreira moral" de Sérgio, ao longo de páginas densas de introspecção psicológica.

$\mathrm{O}$ ingresso numa instituição total implica mudanças significativas na existência do indivíduo, tendo início sua "carreira moral" como internado. "O novato chega ao estabelecimento com uma concepção de si mesmo que se tornou possível por algumas disposições sociais estáveis no seu mundo doméstico", afirma Goffman (1961/1987, p. 24). Já no seu ingresso começa a ser despido desses referenciais identificatórios, começa a passar por uma série de rebaixamentos, degradações, humilhações e profanações do conceito que tinha de si mesmo. Sua "carreira moral" vai passar por mudanças radicais e progressivas, suas crenças a respeito de si mesmo e sobre as pessoas significativas para ele são questionadas, entram em crise e começam a desmoronar. Trata-se de um processo de institucionalização do indivíduo.

Goffman (1961/1987, p. 111) utiliza o termo "carreira moral" em um sentido amplo, com a finalidade de indicar qualquer trajetória percorrida por uma pessoa ao longo de sua vida, permitindo ainda uma perspectiva tanto dos aspectos mais íntimos e pessoais, quanto da posição oficial, jurídica e 
pública do indivíduo, dentro de um complexo institucional. A “carreira moral" indica o processo da vida toda do indivíduo, tanto em direção ao sucesso quanto ao fracasso, dentro da instituição. Esse processo tem momentos típicos, tais como início da vida institucional, crises, evoluções, desenvolvimentos de adaptação, de rebeldia, de submissão, de ruptura etc. Neste estudo, vamos utilizar a idéia de carreira moral para mapear a experiência de internação que Sérgio vivencia no Ateneu.

\section{Instituições modeladoras e produtoras de subjetividade}

As práticas sociais, quaisquer que sejam, produzem subjetividade e subjetivação, produzem também dispositivos de subjetivação. Na perspectiva em que estamos trabalhando, consideramos a subjetividade não como um dado estático e natural, mas como algo que se constitui em processos. Um exemplo é a teorização de Freud, cartografando como é que se constitui a subjetividade humana, com a sua variabilidade e plasticidade pulsional, dependente de uma série de variáveis. A cultura da Formação Capitalista Liberal também modela e produz uma variação de subjetividade que culmina na categoria de indivíduo auto-suficiente, auto-consciente, senhor de si mesmo, o sujeito centrado no eu. Assim como em termos mais amplos, podemos ver a categoria indivíduo como a produção específica de uma modalidade de subjetividade, é nestes termos que, a partir de Goffman (1961/1987), estamos trabalhando com a hipótese de que o modo de funcionamento das instituições totais opera como produtor de certa modalidade da subjetividade.

A produção de subjetividade remete fundamentalmente ao plano micropolítico, microfísico das relações instituintes e instituídas da formação no contexto do internato escolar. Na perspectiva do contexto institucional, as relações formativas (pedagógicas, terapêuticas, educativas) entre a equipe dirigente do Ateneu e os alunos internados não se configuram como relações estáticas entre pólos constituídos, mas apresentam-se em permanente constituição e ordenação - plenas de vicissitudes - em constante transformação dos 
lugares e posições no interior das relações, numa pulverização dos lugares instituídos e instituintes.

Desse modo, não podemos conceber práticas e/ou sujeitos autônomos, pois toda prática é efetivada por relações nas quais se configuram sujeitos. Essa é a principal condição para que as instituições existam concretamente. A solidez institucional residiria nos vínculos entre os sujeitos que as fazem, cotidianamente, vínculos invisíveis, microfísicos. Portanto, as relações instituintes e instituídas do processo formativo no contexto institucional do internato escolar poderiam ser mapeadas a partir das forças e dos poderes moleculares que as permeiam.

\section{A vida de Sérgio antes do ingresso no Ateneu}

O romance se abre com as palavras do pai de Sérgio: "“Vais encontrar o mundo', disse-me meu pai, à porta do Ateneu. 'Coragem para a luta'”. E tudo o que se segue sublinha a ruptura com a vida e o ambiente social representado pela vida familiar, única referência de Sérgio, até aquele momento. A vida no seio da família é definida como "estufa de carinho" (Pompéia, 1888/1997, p. 30) e "conchego placentário" (p. 31). O dado original da ruptura com sua vida cotidiana e "normal" foi matriz de infelicidade para o adulto Pompéia-Sérgio, que não perdoou à vida o ser lançado à indiferença cruel da escola e à convivência com os mais fortes.

Em sua fase de pré-internado, Sérgio vivia com a família e gozava de um status civil correspondente à sua idade, nível sócio-econômico e posição na constelação familiar. Antes de ingressar no Ateneu, ele já havia recebido alguma educação escolar em regime de externato, iniciando sua alfabetização; depois, teve um professor particular (Pompéia, 1888/1997, pp. 30-31).

Inicialmente, Sérgio, deslumbrado pelas festividades que presenciou em duas visitas que fez ao Ateneu (Pompéia, 1888/1997, pp. 33-39), sonha ingressar na escola e triunfar como um bravo, movido por ideais de vitória: 


\begin{abstract}
Mas um movimento animou-me, primeiro estímulo sério da vaidade: distanciavame da comunhão da família, como um homem! Ia por minha conta empenhar a luta dos merecimentos; e a confiança nas próprias forças sobrava. Quando me disseram que estava a escolha feita da casa de educação que me devia receber, a notícia veio achar-me em armas para a conquista audaciosa do desconhecido. (pp. 31-32)
\end{abstract}

Sérgio e seu pai foram recebidos para um jantar na casa do diretor, antes do ingresso do menino no Ateneu. $\mathrm{O}$ garoto estremeceu, quando o diretor lhe afagou a cabeça e falou com ele:

"Como se chama o amiguinho?" - perguntou-me o diretor. "Sérgio..." - dei o nome todo, baixando os olhos e sem esquecer o "seu criado" da estrita cortesia. "Pois meu caro sr. Sérgio, o amigo há de ter a bondade de ir ao cabeleireiro deitar fora esses cachinhos..." Eu tinha os cabelos compridos, por um capricho amoroso de minha mãe. O conselho era visivelmente salgado de censura... (p. 43)

Podemos observar aqui a primeira indicação de uma mudança na aparência pessoal daquele que vai ser internado na instituição escolar. O corte de cabelos de Sérgio é o símbolo das transformações pelas quais vai passar, ao deixar o ambiente doméstico. “... É a infância que ali fica, nos cabelos louros..." comenta Ema, esposa de Aristarco, colhendo os cabelos do menino entre os dedos e sugerindo que ele os oferecesse à sua mãe como recordação (p. 44).

\title{
O primeiro dia no internato
}

Sérgio ingressou no colégio interno voluntariamente e pleno de expectativas otimistas. Depois dos acertos na secretaria, ao menino foi designado um lugar no dormitório dos médios; havia também dormitórios para os menores e para os grandes, todos coletivos. As roupas de Sérgio foram guardadas na "rouparia", na gaveta que lhe foi designada, de número 54.

Quando meu pai saiu, vieram-me lágrimas, que eu tolhi a tempo de ser forte. Subi ao salão azul, dormitório dos médios onde estava minha cama; mudei de roupa, levei a farda ao número 54 do depósito geral, meu número. Não tive coragem de afrontar o recreio. Via de longe os colegas, poucos àquela hora, passeando em gru- 
pos, conversando amigavelmente, sem animação, impressionados ainda com as recordações de casa; hesitava em ir ter com eles, emb araçado da estréia das calças longas, como um exagero cômico, e da sensação de nudez à nuca, que o corte recente dos cabelos desabrigara em escândalo. (Pompéia, 1888/1997, p. 49)

Um dos inspetores o animou a entrar em contato com os outros meninos. Observamos que uma vez no internato, o menino se distanciou e procurou permanecer fora de contato com os demais, numa estratégia exploratória de conhecimento da nova realidade. Podemos especular que se tratava de uma criança tímida, pouco desenvolvida para seus onze anos (Pompéia, 1888/1997, p. 43), bonita e evasiva, mais propensa para o medo do que para a assertividade. Sérgio foi solicitado pelos colegas internados a sair desse anonimato e ausência, implicando-se na interação social convencional na comunidade escolar. Quando Sérgio aceitou sua nova posição de internado, começou a passar por um processo que é comum a toda uma classe de estabelecimentos segregadores - cadeias, conventos, mosteiros, campos de concentração ou de trabalho forçado etc. - nos quais o indivíduo passa um longo período de sua vida confinado na instituição e vive rotineiramente sob a disciplina e vigilância de uma equipe dirigente, na companhia de um grupo de companheiros que possuem igual status institucional (Goffman, 1961/1987).

O novato na instituição começa a perceber que está despojado de muitas de suas defesas, satisfações, afirmações e apoios costumeiros. Agora ele passa a estar sujeito a um conjunto relativamente completo de experiências de mortificações (Goffman, 1961/1987, p. 24): restrição do movimento livre para ir e vir, vida comunitária compulsória, autoridade difusa de toda uma escala de pessoas etc.

Na sua primeira aula no internato (Pompéia, 1888/1997, pp. 49-51), Sérgio foi apresentado pelo professor Mânlio aos seus colegas, sendo recomendado a um aluno mais velho e sério da turma, o Rebelo, aluno estudioso, atento e que usava óculos por causa de dificuldades visuais. O autor descreveu seus companheiros de classe de modo irônico e sarcástico, ressaltando os defeitos dos colegas, de uma perspectiva pessoal nitidamente elitista. "Entretinha-me a espiar os companheiros, quando o professor pronunciou o 
meu nome. Fiquei tão pálido que Mânlio perguntoutme, brando, se queria ir à pedra. Precisava examinar-me. De pé, vexadíssimo, senti abrumar-me a vista, numa fumaça de vertigem..." (p. 51). Sérgio desmaiou, sentindo-se sob o olhar dos colegas. O menino despertou na rouparia, sob os cuidados de Rebelo. "Rebelo retiroutse e eu, em camisa, acabrunhado, amargando o meu desastre, enquanto o roupeiro procurava o gavetão 54, fiquei a considerar a diferença daquela situação para o ideal de cavalaria com que sonhara assombrar o Ateneu" (p. 51). Ainda na rouparia, Sérgio se entreteve com um folheto pornográfico, que devia pertencer ao roupeiro. Mais uma decepção e ao mesmo tempo um símbolo dos aspectos eróticos da vida íntima do internado, com os quais logo Sérgio iria se enfrentar (p. 52).

Ao sair para o pátio, Sérgio conversou com Rebelo que lhe descreveu os colegas do internato, carregando nas tintas e apresentando-os negativamente. Sérgio foi perseguido por alguns de seus colegas de internato (p. 54), que o provocaram ostensivamente e o obrigaram a reagir e revidar com violência. Isso pode ser entendido como uma tentativa, por parte dos veteranos, de obter a cooperação inicial do novato, de tentar submetê-lo com o objetivo de se aproveitarem dele posteriormente. “... Faça-se forte aqui, faça-se homem. Os fracos perdem-se." - havia lhe recomendado outro colega, o Rebelo (um autêntico convertido, que assume em sua fala, o discurso oficial da escola) - “... Faça-se homem, meu amigo! Comece por não admitir protetores" (p. 54).

Quando Rebelo foi para a aula, Sérgio viu-se sozinho. Ele permaneceu na órbita de um dos inspetores que "fiscalizava o recreio, graduando a folgança... um pouco além da cadeira do Silvino, fiquei a salvo" (p. 55). Os recém-chegados eram chamados de calouros ou novatos e, segundo Sérgio, “... Eram os pobres novatos que os veteranos sovavam à cacholeta, fraternalmente" (p. 56), durante os recreios coletivos onde todos se misturavam. Vemos que depois da admissão oficial, Sérgio passou a ficar exposto aos usuais processos de "mortificação do eu" que Goffman (1961/1987, p. 24) descreve com clareza. Sérgio procurou se aproximar de Franco, bode expiatório do colégio, que estava de castigo novamente, mas este não lhe deu atenção. 
Provocado por Barbalho, um colega de internato que o perseguiu durante este dia, Sérgio acabou tendo uma briga com ele:

foi à noite, pouco antes da ceia. Estávamos a um canto mal iluminado do pátio, quase a sós. O biltre reconheceu-me e arreganhou uma inexprimível interjeição de mofa. Não esperei por mais. Estampei-lhe uma bofetada. Meio segundo depois, rolávamos na poeira, engalfinhados como feras. Uma luta rápida. Avisaram-nos que vinha o Silvino. Barbalho evadiu-se. Eu verifiquei que tinha o peito da blusa coberto de sangue que me corria do nariz. Uma hora mais tarde, na cama de ferro do salão azul, compenetrado da tristeza de hospital dos dormitórios, fundos na sombra do gás mortiço, trincando a colcha branca, eu meditava o retrospecto do meu dia. (Pompéia, 1888/1997, p. 57)

Sérgio, decepcionado, meditou sobre o contraste entre suas aspirações ideais iniciais e a realidade do internato de que tivera uma amostra em seu primeiro dia. Era assim selvagem e cruel o colégio. Sérgio ficou sozinho e se sentiu abandonado, uma vez perdidas as ilusões idealizadas da vida nova no internato.

... Era o ermo. E, na solidão, conspiradas as adversidades de toda a espécie, fals idade traiçoeira dos afetos, perseguição da malevolência, espionagem da vigilância; por cima de tudo, céu de trovão sobre os desalentos, a fúria tonante de Júpiterdiretor, o tremendo Aristarco dos momentos graves. (p. 58)

Sérgio chorou sua solidão, abandono e tristeza, mergulhando na mais completa anomia.

\section{Estratégias adaptativas}

O internado precisa se adaptar aos processos de admissão, mortificação e ao sistema de privilégios da vida institucional (Goffman, 1961/1987). Tal adaptação pode produzir-se de diferentes modos e o internado empregará diversas táticas adaptativas em distintos momentos de sua "carreira moral", podendo também alternar entre várias estratégias ao mesmo tempo. 
Goffman (1961/1987, p. 59) descreve diversas estratégias de adaptação do indivíduo às condições ambientais da instituição total: afastamento da realidade, no qual o internado se abstém através de graus variados de não-participação em acontecimentos e interações; intransigência, em que o internado desafia intencionalmente a instituição, ao negar-se de modo visível a cooperar com a equipe dirigente (a rebeldia costuma ser uma forma de reação inicial e temporária; depois, o internado se utiliza de outras táticas adaptativas); colonização, onde o indivíduo se adapta de tal modo à instituição, que nela acaba por encontrar um lar, acreditando e sentindo que vive no melhor dos mundos e nunca teve nada melhor antes, usufruindo o máximo possível do que lhe propicia a vida institucional; conversão, na qual o internado parece aceitar a interpretação oficial da equipe dirigente e procura representar o papel do internado perfeito (o convertido aceita uma tática disciplinada, moralista e monocromática, apresentando-se como alguém cujo entusiasmo pela instituição está sempre à disposição da equipe dirigente); "se virar": as táticas anteriores representam comportamentos coerentes que podem ser seguidos, mas os internados não perseveram nelas por muito tempo. Eles acabam "se virando" e utilizam um "jogo de cintura": uma combinação oportunista de ajustamentos secundários, conversão, colonização e lealdade aos colegas, de modo a obter, dentro da situação específica, uma possibilidade máxima de evitar sofrimentos físicos ou psicológicos.

Um incidente na piscina onde os alunos internados tomavam banho conduziu Sérgio a uma de suas estratégias adaptativas. Um internado maior que Sérgio arrasta-o para a parte funda da piscina, sem ser visto, criando um pretexto para salvar o garoto e se aproximar dele, numa estratégia nitidamente perversa, com a qual infunde medo e pavor e depois se oferece como salvador. O estratagema funcionou e Sérgio ficou amigo íntimo de Sanches, que o salvara (Pompéia, 1888/1997, p. 59).

A partir dessa fase introdutória de "aclimatação", como diz o próprio autor, podemos observar o desenrolar da "carreira moral" do menino Sérgio: depois de um esforço inicial para ser bom estudante, ele passa por uma experiência de sedução, cai na vadiagem e, finalmente, é publicamente humilhado pelo diretor por suas más notas. "Já me era lícito julgar iniciado na 
convivência íntima da escola... estava aclimado, mas eu me aclimara pelo desalento, como um encarcerado no seu cárcere" (Pompéia, 1888/1997, p. 62). Sérgio se sentiu desanimado, privado dos seus ideais ingênuos e acovardado. Esquece-se do alerta de Rebelo e desejou um protetor que o ajudasse naquele meio hostil. Sérgio se deixou namorar pelo vigilante, buscando proteção e um auxílio nos estudos.

\footnotetext{
... Pouco a pouco me ia invadindo a efeminação mórbida das escolas... sentia-me possuído de uma certa necessidade preguiçosa de amparo, volúpia de fraqueza em rigor impróprio do caráter masculino. Convencido de que a campanha do estudo e da energia moral não era precisamente uma cavalgada cotidiana, animada pelo clarim da retórica, como nas festas, e pelo verso enfático dos hinos, entristeceu-me a realidade crua. Desiludi-me dos bastidores da gloriosa parada, vendo-a pelo avesso. Nem todos os dias do militarismo enfeitam-se com a animação dos assaltos e das voltas triunfais; desmoralizava-me o ranram estagnado da paz das casernas, o prosaísmo elementar da faxina. (p. 63)
}

A situação psicológica de Sérgio era de desamparo, medo e receio, diante da agressiva realidade do Ateneu. "O braço de Sanches vinha assim salvar-me, segunda vez, de submersão, acudindo na vertigem do momento" (p. 63). "Descrente da fraternidade do colégio, cuja personificação representava-me o Barbalho, eu temia o alvoroço do recreio. Conservar-me na sala das lições era uma medida de prudência" (p. 67).

Sanches se tornou o protetor de Sérgio e o ajudou com os estudos, mas suas intenções sexuais a respeito do menino foram num crescendo dos gestos e proximidade física. Sérgio "deixava tudo, fingindo-me insensível" (p. 68). Queria romper com o outro, mas não tinha coragem. Sérgio não via mal no comportamento do outro e, embora não gostasse daquela proximidade viscosa, não se manifestava com clareza. $\mathrm{O}$ outro, diante desse silêncio tácito, deveria se sentir mais estimulado.

Às vezes a minha resistência passiva desapontava o preceptor. Ele encarava-me terrível, e como quem diz: "perde a proteção de um vigilante!", ou disfarçava a impertinência em riso amarelo, numa abstrata expressão de fisionomia, que era aliás o facies de uma idéia fixa. (p. 69) 
Até que Sanches lhe fez uma proposta aberta, balbuciando-lhe uma pergunta. Sérgio decepcionou o pretendente por sua inocência, e o vigilante se afastou, frio. Diante da ingenuidade do menino, Sanches se dedicou a prestar-lhe, sem ser solicitado, esclarecimentos sobre "as coisas da vida" para as quais o seu protegido era inocente. Era mais uma estratégia sedutora, como quem prepara o terreno e semeia, para uma futura colheita.

Eu me sentia amesquinhado sob o peso das revelações. Causava terror aquela sabedoria de coisas nunca sonhadas. $\mathrm{O}$ honrado diretor espiritual percebeu que havia agora um ascendente de domínio que me curvava. (Sanches) olhava-me então de frente e tinha ousados risos de malícia. Depois de dias de reserva, chegou-se de novo com uma segurança de possuidor forte. (p. 71)

Estavam sempre juntos, Sanches e Sérgio, com o pretexto de estudar. Sanches passeava com o menino por lugares pouco iluminados, abraçando-o e tocando-o nervosamente. Sérgio suportava o comportamento do outro, num deplorável estado de energia. "Eu aturava, imaginando em resignado silêncio o sexo artificial da fraqueza, que definira Rebelo" (p. 71). O outro, estimulado pela aparente entrega e assentimento tácito do pupilo, voltou à carga e fez-lhe nova proposta. Sérgio reagiu com asco e evadiu-se, rompendo com seu protetor, perdendo o amigo, o explicador e o vigilante.

Sanches, auxiliar responsável por supervisionar a turma de Sérgio, membro da equipe de vigilantes nomeados por Aristarco, retalia ao ser rechaçado, perseguindo o menino, que fracassou num exame e foi desmoralizado com repreensão solene, para grande regozijo do despeitado pretendente. Sérgio decidiu então vadiar, chegando a ponto de ficar excluído de qualquer qualificação decente, até tornar-se o último da classe. A vadiagem de Sérgio pode ser entendida como uma estratégia de rebeldia passiva em um novo estilo de adaptação. "Fui o último da aula! Resultado razoável, para emprego de uma energiazinha que despontava” (Pompéia, 1888/1997, p. 72).

O menino ficou solitário e calado, não ousando se aproximar de nenhum outro colega depois da experiência com Sanches. Este, “...rancoroso, perseguia-me como um demônio. Dizia coisas imundas. 'Deixa estar, jurava entre dentes, que ainda hei de tirar-te a vergonha'. Na qualidade de vigilante, 
levava-me brutalmente à espada. Eu tinha as pernas roxas de golpes; as canelas me incharam" (p. 77).

Sérgio fazia alguns esforços para reerguer-se e ninguém percebia, diante do que o menino foi se resignando, insensível, no seu desmoronamento. Passou, então, a alimentar a fantasia de martírio: seu sofrimento o tornaria um santo. Reagindo à tentativa de aliciamento pelo vigilante Sanches, desiludido dos ideais de trabalho e fraternidade que esperava encontrar no colégio, Sérgio mergulha numa fase religiosa e mística:

Perdido o ideal cenográfico de trabalho e fraternidade, que eu quisera que fosse a es cola, tinha que soltar para outras bandas os pombos da imaginação. Viveiro seguro era o céu. Ficava-me a vendagem da eterna felicidade, que não se contava. (p. 74)

Sérgio era devoto de Santa Rosália (p. 78) e desfrutava dos momentos de oração e cânticos religiosos que os alunos eram obrigados a entoar no colégio, sobretudo no mês de maio (pp. 80-82), que era dedicado à Virgem Maria. Mas o menino não admitia confissão, nem a comunhão, estranhava o exagero do culto público e tinha antipatia pelos "homens de batina". Seu misticismo era um sentimento privado. Uma forma de racionalizar, justificar e elaborar os sofrimentos aos quais estava exposto no ambiente do colégio interno.

Todos os dias no café da manhã, o diretor do Ateneu comentava em voz alta o desempenho acadêmico de cada aluno. Quando Sérgio foi chamado por Aristarco, durante a leitura do livro de notas, devido ao seu fracasso nos exames, “... A congregação justiceira dos colegas voltou-se para mim, contra mim. Os vizinhos de lugar à mesa se afastaram dos dois lados, para que eu melhor fosse visto" (Pompéia, 1988/1997, p. 76). O menino tremia, mas na primeira vez, o diretor foi clemente. Vieram, porém, as reincidências e

\footnotetext{
... Aristarco não perdoou mais. Houve ainda terceira, quarta, por diante. Cada uma delas doía-me intensamente; contudo não me indignavam. Aquele sofrimento eu o desejava, na humildade devota da minha disposição atual. Chorava à noite, em segredo, no dormitório; mas colhia as lágrimas numa taça, como fazem os mártires das estampas bentas, e oferecia ao céu, em remissão dos meus pobres pecados, com as notas más boiando. (p. 77)
} 
Um segundo momento nesta etapa religiosa de Sérgio foi bastante desagradável, centrado nos aspectos mais ameaçadores da doutrina cristã: "Iniciara-me Sanches no Mal: Barreto instrui-me na Punição. Abria a boca e mostrava uma caldeira do inferno; as palavras eram chamas; ao calor daquelas práticas, as culpas ardiam como sardinhas em frege" (p. 94). Sérgio começou a achar a religião "de insuportável melancolia. Morte certa, hora incerta, inferno para sempre, juízo rigoroso; nada mais negro!” (p. 95). Seu fervor religioso começou a declinar.

O período místico de Sérgio terminou depois de uma aventura, uma autêntica embrulhada na qual ele se meteu com Franco, de quem se tornara muito próximo. Este queria se vingar das muitas humilhações que sofria por parte de todos e decidiu espalhar cacos de vidro na piscina da "natação". O remorso e a culpa transtornaram Sérgio e ele acabou adormecendo na capela, rezando em angústia, incapaz de delatar o colega. Nada aconteceu de grave, felizmente (pp. 86-92). Sérgio resolveu mudar de atitude e sair do marasmo em que se afundava, abandonando o período de vadiação profunda e amolecimento hipnótico nos quais o mergulhou a atmosfera do Ateneu, suavizada apenas pela sua devoção religiosa. Quis se fazer independente. Pensamos que Sérgio se utilizou inicialmente da tática do afastamento da situação, como um modo de adaptação, depois do choque inicial. Ele se deixou levar pela corrente. Num segundo momento, resolveu reagir e passou a adotar uma postura mais intransigente e rebelde, mudando de estratégia. Sérgio passou para uma rebeldia ativa e solitária.

Sérgio se deu conta de que chegou ao fundo do poço, ficou perplexo e buscou um modelo entre os colegas, com o qual se pudesse identificar.

O triunfo da escola poderia ser o Sanches; em compensação, humildade vencida era o Franco. Entre os dois extremos repugnantes, revelavam-se três amostras típicas à linha do bem-viver: Rebelo, um ancião; Ribas, um angélico; Mata, o corcunda, um polícia secreta. Para angélico decididamente não tinha jeito, estava provado, nem omoplatas magras; para ancião, não tinha idade, nem óculos azuis, nem mau hálito; para ser o Mata, faltava-me justo o caráter e a corcova... Onde estava o dever?... (Pompéia, 1888/1997, p. 92) 
Quando foi visitar a família, Sérgio informou a seu pai tudo o que estava vivendo no colégio, relatou-lhe suas dificuldades, procurando obter ajuda para reagir. $\mathrm{O}$ menino obteve sucesso total em sua entrevista com o pai. Essa reação de Sérgio vem lembrar à instituição que ela deve considerar o status e relações sociais do internado no mundo externo: o estabelecimento deve respeitar alguns dos direitos do internado como pessoa. Neste caso, os parentes de Sérgio lembram à equipe dirigente suas obrigações quanto a padrões humanitários e direitos do indivíduo. O próprio estudante desempenha bem esse papel.

Dias depois, no colégio, eu era um pequeno potentado. Derrubei o Sanches; consegui revogação da disciplina das espadas; reconquistei a benevolência de Mânlio (o professor); levantei a cerviz! Desembaraçado do arbítrio pretensioso de um vigilante, o trabalho agradou-me. (...) Com uma palavra fez-se um anarquista. Daí por diante era fatal o conflito entre a independência e a autoridade. Aristarco tinha de roer. Em compensação, adeus esperanças de ser um dia vigilante! Adeus indolência feliz dos tempos beatos. (Pompéia, 1888/1997, p. 98)

Sérgio estabeleceu para si um novo programa, pautado pela "razoável mediocridade sem compromissos", desprezando com vaidade prêmios, aplausos, não quis se tornar exemplar nem pagar o preço de se tornar um aluno modelo. Os superiores desenvolveram uma antipatia pelo menino e "invejosos da minha altivez, os inimigos fizeram partido. Sanches era o chefe, na cortina: Barbalho era o líder abertamente. Eu sorria vaidoso, levando de vencida a guerrinha, como a espuma à proa de um barco" (p. 99). Esse foi o caráter que Sérgio procurou manter, depois de algumas oscilações em sua carreira moral. Podemos dizer que ele assumiu uma estratégia de adaptação que consistia em certa intransigência irônica e na "viração", procurando combinar de modo oportunista várias estratégias e "jogo de cintura" para evitar sofrimentos e usufruir o possível da vida no estabelecimento.

Na etapa seguinte de sua carreira moral, Sérgio assumiu gentilmente o papel de namorada platônica de Bento Alves e se deixou cortejar, necessitado da proteção de um companheiro forte no ambiente hostil do Ateneu. 


\section{Produção de Subjetividade no "Ateneu"}

Bento Alves era um misterioso. Mistérios são no colégio os que não andam a atravancar o espaço com as gatimanhas das suas expansões. Freqüentava as aulas superiores; sem que fosse um estudante de rumoroso mérito, fazia-se respeitar dos mestres e condiscípulos. Sisudo como certos rapazes de inteligência menor que se arreceiam do ridículo, não somente pela sisudez impunha-se ao respeito. Consideravam-no principalmente pela nomeada de hercúleo. Os fortes constituem realmente uma fidalguia de privilégios no internato. No tumulto da existência em comum, fundem-se as distinções de classe na democracia do coleguismo; as cambiantes de fortuna apagam-se no figurino geral das blusas pardas. Os títulos de superioridade prevalecem primitivamente no critério semibárbaro dos verdes anos; o punho válido chega a fazer vantagem sobre a própria vantagem do favoritismo. (p. 108)

Alves não alardeava de forte; evitava disputas, não jogava o pulso, preferia exerc itar-se à ginástica sem espectadores. Às vezes, por brinquedo, cingia o braço a um colega entre o polegar e o médio e fechava-lhe sob a manga um bracelete roxo dolorido. Aqueles que se sujeitavam ao formidável ensaio de tatuagem por compressão, acercavam-se, daí por diante de Bento Alves com os escrúpulos da mais reservada prudência. (Pompéia, 1888/1997, pp. 108-109)

Entretanto era mole, da preguiça monumental dos animais pujantes. Veloz, detestava a carreira; alegre, fugia aos folguedos. Gostava do seu sossego; desviava os incômodos da convivência distribuída, transbordante dos estimados. Não se falava dele no Ateneu. Limitavam-se a temê-lo em silêncio. (p. 109)

A amizade de Bento Alves por mim, e a que nutri por ele, me faz pensar que, mesmo sem o caráter de abatimento que tanto indignava ao Rebelo, certa efeminação pode existir como um período de constituição moral. Estimei-o femininamente, porque era grande, forte, bravo; porque podia me valer; porque me respeitava, quase tímido, como se não tivesse ânimo de ser amigo. Para me fitar, esperava que eu tirasse dele os meus olhos. A primeira vez que me deu um presente, gracioso livro de educação, retirou-se corado, como quem foge. Aquela timidez, em vez de alertar, enternecia-me, a mim que aliás devia estar prevenido contra escaldos de água fria. Interessante é que vago elemento material havia nesta afeição de criança, tal qual se nota em amor, prazer no contato fortuito, de um aperto de mãos, da emanação da roupa, como se absorvêssemos um pouco do objeto simpático. (p. 116)

Na biblioteca, Bento Alves escolhia-me as obras: imaginava as que me podiam interessar; e propunha a compra, ou as comprava e oferecia ao Grêmio, para dispensar-se de mas dar diretamente. No recreio não andávamos juntos; mas eu via de 


\section{Sílvio José Benelli}

longe o amigo, atento, seguindo-me o seu olhar como um cão de guarda. Soube depois que ameaçava torcer o pescoço a quem pensasse apenas em me ofender; seu irmão adotivo! confirmava. Eu, que desde muito assumira entre os colegas um belo ar de impávida altania, modificava-me com o amigo, e me sentia bem na submissão voluntária, como se fosse artificial a bravura, a maneira da conhecida petulância feminina. (p. 117)

Bento Alves desenvolveu e manteve com Sérgio uma relação amorosa platônica e repleta de cuidados do mais velho com o mais jovem.

No movimento geral da existência do internato, desvelava-se caprichosamente; sabia ser, de modo inexprimível, fraternal, paternal, quase digo amante, tanta era a minudência dos seus cuidados. Não havia regalo, dessas mesquinhas coisas de preço enorme na carestia perpétua da prisão escolar, de que não se privasse o Alves, em meu proveito, desesperando-se, a fazer pena, se eu tentasse recusar. À conversa, falava da família no Rio Grande do Sul; tinha duas irmãs; falava delas, do tempo passado que não as via, muito claras, de belos olhos, uma de quinze anos, outra de doze; ele tinha dezoito. Falava de cuidados higiênicos meus, mudar de cama no salão azul, que estava muito perto das janelas e isto havia de ser nocivo... Outras ninharias, em tom de sentida brandura, como se desejasse decrescer das proporções sólidas de sua conformação para reduzir-se à exiguidade balbuciante de uma carcaçazinha de avó, minguada de velhice, animada ainda e apenas pela febre do último alento, pela necessidade de carregar ainda alguns dias um coração, um afeto. (pp. 117-118)

O meu bom amigo, exagerado em mostrar-se melhor, sempre receoso de importunar-me com uma manifestação mais viva, inventava cada dia nova surpresa e agrado. Chegara ao excesso das flores. A princípio, pétalas de magnólia seca com uma data e uma assinatura, que eu encontrava entre folhas de compêndio. As pétalas começaram a aparecer mais frescas e mais vezes; vieram as flores completas. Um dia, abrindo pela manhã a estante numerada do salão do estudo, achei a imprudência de um ramalhete. Santa Rosália da minha parte nunca tivera um assim. Que devia fazer uma namorada? Acariciei as flores, muito agradecido, e escondi-as antes que vissem. (p. 131)

Os inimigos de Sérgio, Barbalho e seu grupo, não estavam alheios ao que se passava. O romance secreto de Sérgio e Bento Alves certamente não passava desapercebido aos olhos dos colegas internados, sobretudo dos inimigos que não dormem. À aversão desse grupo por Sérgio, juntourse a inve- 
ja ao Bento Alves, que se tornou herói no Ateneu ao render um dos empregados da casa que cometeu um assassinato (pp. 102-103).

Mas o Barbalho espiava, ultimamente constituído fiscal oculto dos meus passos. As circunstâncias o tinham aproximado do Malheiro, e o açafroado caolho pretendia manejar a rivalidade dos dois maiores: um conflito entre Malheiro e Bento poderia ser a vergonha para mim. (p.131)

Malheiro passou a perseguir Sérgio, infernizando-o com provocações e insinuações:

Queria incomodar o Alves, mortificando-me, julgando que me queixasse. Eu devorava as afrontas do marmanjo sem descobrir o meio de tirar correta desforra. Depois de incitar o Malheiro contra mim, incitou o Bento contra o Malheiro. Procurou-o misteriosamente e informou: "O Malheiro não passa pelo Sérgio sem que pergunte quando é o casamento... é preciso casar... Ainda hoje pediu convite para as bodas. O Sérgio está desesperado.". O furor do Alves não se descreve, furor poderoso dos calados. Uma onda de apoplexia ruborizou-lhe as faces. Por um único movimento de indignação contraiu os dedos, como se estrangulando. Procurou o Malheiro e com a voz talvez alterada, mas sem ódio, fez intimação: "Amanhã é a sessão de encerramento; em meio da festa saímos ambos; preciso falar-lhe das bodas." Malheiro percebeu: era o sonh ado encontro! (Pompéia, 1888/1997, pp. 131-132)

No momento marcado, quando ambos saíram do auditório, Sérgio adivinhou o que acontecia. Terminadas as atividades acadêmicas, Sérgio saiu para o pátio e recebeu uma carta do Alves: "Estou preso; antes que te digam que por alguma indignidade, previno: por ter dado uma lição ao Malheiro" (p. 132).

Enquanto Alves e Malheiro lutavam, Barbalho foi denunciá-los ao diretor e no fim da luta, Bento Alves foi surpreendido com uma ordem de prisão do diretor. Os dois contendores recusaram-se a dar explicações. "Não denunciar nunca é preceito sagrado de lealdade no colégio" (p. 132). Malheiro apanhou bastante.

Sérgio foi ver o amigo na prisão.

Por minha parte, entreguei-me de coração ao desespero das damas romanceiras, montando guarda de suspiros à janela gradeada de um cárcere onde se deixava de- 


\section{Sílvio José Benelli}

ter o gentil cavalheiro, para o fim único de propor assunto às trovas e aos trovadores medievos. (p. 132)

O tempo passou no internato. "Bento Alves, depois de assegurar que unicamente por mim se havia sujeitado à humilhação que sofrera, andava propositalmente arredio" (p. 139). Mais tarde, os dois amigos voltaram ao antigo relacionamento.

As simpatias do excelente companheiro não tinham diminuído. Durante as férias, fora ver-me em casa, travando relações com a minha família. Fui recomendado insistentemente ao amigo, que me valesse, nas dificuldades da vida colegial, contra o constante perigo da camaradagem perniciosa. Durante o mês de janeiro não nos vimos. Por ocasião da abertura das aulas, notei-lhe um calor novo na amizade, sem efusões como dantes, mas evidentemente testemunhado por tremores da mão ao apertar a minha, embaraços na voz de amoroso errado, bisonho desviar dos olhos, denunciando a relutância de movimentos secretos e impetuosos. Às vezes mesmo, um reflexo assustador de loucura acentuava-se-lhe nos traços. (Pompéia, 1888/1997, p. 162)

Interessava-me aquela agonia comprimida. Estranha coisa, a amizade que, em vez da aproximação franca dos amigos, podia assim produzir a incerteza do mal-estar, uma situação prolongada de vexame, como se a convivência fosse um sacrifício e o sacrifício uma necessidade. (p. 162)

Durante os primeiros dias do ano, poucos alunos chegados, ficávamos horas inteiras em companhia. Trouxera-me um presente de livros, com dedicatória a cores, de bela caligrafia, inscritas em rosas entrelaçadas de cromo. Recordo-me também de um dulcíssimo cofre dourado de pastilhas e outras ridicularias de amabilidade que me oferecia, passado de vergonha pela insignificância do obséquio. Confusamente, ocorria-me a lembrança do meu papelzinho de namorada faz-de-conta, e eu levava a seriedade cênica a ponto de galanteá-lo, ocupando-me com o laço de gravata dele, com mecha de cabelos que lhe fazia cócegas aos olhos; soprava-lhe ao ouvido segredos indistintos para vê-lo rir, desesperado de não perceber. Uma das irmãs casara no Rio Grande; ele mostrou-me o retrato do noivo, um par de bigodes negros descaídos, com a noiva, um rosto oval correto e puro, o turbilhão nevoento dos véus. Deu-me um botão de flor de laranjeira que tinham remetido. (p. 162)

As coisas corriam assim serenas, quando não mais que de repente, houve uma mudança radical. Bento Alves inexplicavelmente atacou Sérgio e 
lutou com ele, num desvairamento completo. Espancado pelo amigo irreconhecível e forte, Sérgio defendeu-se como pode, atacando-o com um sapato velho (p. 163).

Aristarco surpreendeu a briga e Bento Alves retirourse. O diretor exigiu explicações de Sérgio que lhe respondeu com violência. Aristarco enfureceu-se e suspendeu o rapaz pela roupa, ameaçando-o e exigindo explicações. Sérgio agarrou-lhe os bigodes, aturdido, esperneando, contorcendo-se, sem observar as "conveniências do respeito". Aristarco soltou o rapaz, escandalizado, sentindo-se ultrajado por ter sido agarrado pelos bigodes: "Criança! Feriste um velho!... Ah! Meu filho, ferir a um mestre é como ferir ao próprio pai e os parricidas serão malditos" (Pompéia, 1888/1997, pp. 163-164).

O tom comovido deste final inesperado impressionou-me até o íntimo da alma. Estava vencido. Fiquei por um minuto horrorizado de mim mesmo. De volta do atordoamento, achei-me só no corredor. A saída dramática do diretor aumentou-me ainda os remorsos. Houve uma reação de esforço moral e desatei nervosamente em pranto, chorei a valer, amparando-me ao peitoril de uma janela. Contava certo com um castigo excepcional, uma cominação qualquer do célebre código do arbítrio, em artigo cujo grau mínimo fosse a expulsão solene. (p. 164)

Sérgio esperou alguns dias pelo castigo que não veio.

... Bento Alves despedira-se do Ateneu na mesma tarde do extraordinário desvario. Acreditei algum tempo que a minha impunidade era um caso especial do afamado sistema das punições morais e que Aristarco delegara ao abutre da minha consciência o encargo da sua justiça e desafronta. (p. 164)

Depois, Sérgio concluiu que não compensava, para o diretor, perder duas mensalidades de uma só vez, além do que o incidente, embora desagradável, não teve testemunhas. "O caso morreu em segredo de discrição, encontrando-nos eu e o diretor num conchavo bilateral de reserva, como se nada houvesse" (p. 164). 
Sérgio no secundário

Ao passar para o secundário, Sérgio faz um balanço do seu tempo e experiência de internação no colégio, refletindo sobre sua ingenuidade infantil inicial e todas as suas decepções posteriores. O colégio passa definitivamente a representar um cárcere para o adolescente. Agora ele já era um veterano no Ateneu e conhece bem os meandros da vida na instituição. Inicia-se uma nova etapa em sua carreira moral. O tempo da novidade foi seguido pelo da desilusão e do sofrimento. À continuação, veio a resignação cética.

Depois dos exames primários (Pompéia, 1888/1997, pp. 146-148), enquanto esperava com os colegas a leitura da lista dos aprovados, Sérgio contempla os quadros de alto relevo nos quais, representando as artes e indústrias, meninos nus feitos de gesso, dançam em roda fraternal. Sérgio refletiu:

Senti-me velho. Que longa viagem de desenganos! Alguns meses apenas, desde que vira, à primeira vez, as ideais crianças vivificadas no estuque pelo contágio do entusiasmo ingênuo, ronda feliz do trabalho... Agora, um por um que os interpretasse, aos pequenos hipócritas mostrando as nádegas brancas com um reverso igual de candura, um por um que os julgasse, e todo aquele gesso das facezinhas rechonchudas coraria de uma sanção geral e esfoladora de palmadas. Não me enganavam mais os pequeninos patifes. Eram infantis, alegres, francos, bons, imaculados, saudáveis dos primeiros anos, tempos da escola que não voltam mais!... E mentiam todos!... Cada rosto amável daquela infância era a máscara de uma falsidade, o prospecto de uma traição. Vestia-se ali de pureza a malícia corruptora, a ambição grosseira, a intriga, a bajulação, a covardia, a inveja, a sensualidade brejeira das criaturas eróticas, a desconfiança selvagem da incapacidade, a emulação deprimida do despeito, a impotência, o colégio, barbaria de humanidade incipiente, sob o fetichismo do Mestre, confederação de instintos em evidência, paixões, fraquezas, vergonhas que a sociedade exagera e complica em proporção de escala, respeitando o tipo embrionário, caracterizando a hora presente, tão desagradável para nós, que só vemos azul o passado, porque é ilusão e distância. (p. 148)

No ano seguinte, o Ateneu revelou-se noutro aspecto. Conhecera-o interessante, com as seduções do que é novo, com as projeções obscuras de perspectiva, desafiando curiosidade e receio; conhecera-o sípido e banal como os mistérios resolvi- 


\section{Produção de Subjetividade no "Ateneu"}

dos, caiados de tédio; conhecia-o agora intolerável como um cárcere, murado de desejos e privações (p. 151)

Depois das férias, quando esteve em contato com a vida social corrente, aumenta sua consciência dos limites da vida no internato escolar:

Comecei a penetrar a realidade exterior como palpava a verdade da existência no colégio. Desesperava-me então ver-me duplamente algemado à contingência de ser irremissivelmente pequeno e ainda colegial. Colegial, quase calceta! marcado com um número, escravo dos limites da casa e do despotismo da administração. (p. 152)

Sérgio inicia uma nova amizade na sua fase de colegial. Egbert é seu novo amigo. "Adquirira-o com a transição para as aulas secundárias, onde o encontrei com outros adiantados. Vizinhos de banco, compreendemo-nos, mutuamente simpáticos, como se um propósito secreto de coisa necessária tivesse guiado o acaso da colocação" (Pompéia, 1888/1997, p. 169).

Conheci pela primeira vez a amizade. A insignificância cotidiana da vida escolar em que a gente se aborrece, é favorável ao desenvolvimento de inclinações mais sérias que as de simples conveniência menineira. $\mathrm{O}$ aborrecimento é um feitio da ociosidade, e da mãe proverbial dos vícios gera-se também o vício de sentir. (p. 169)

A convivência do Sanches fora apenas como o afeiçoamento aglutinante de um sinapismo, intolerável e colado, espécie de escravidão preguiçosa da inexperiência e temor; a amizade de Bento Alves fora verdadeira, mas do meu lado havia apenas gratidão, preito à força, comodidade da sujeição voluntária, vaidade feminina de dominar pela fraqueza, todos os elementos de uma forma passiva de afeto, em que o dispêndio de energia é nulo, e o sentimento vive de descanso e de sono. Do Egbert, fui amigo. Sem mais razões, que a simpatia não se argumenta. Fazíamos os temas de colaboração; permutávamos significados, ninguém ficava a dever. Entretanto, eu experimentava a necessidade deleitosa da dedicação. Achava-me forte para querer bem e mostrar. Queimava-me o ardor inexplicável do desinteresse. Fgbert merecia-me ternuras de irmão mais velho (pp. 169-170)

Tinha o rosto irregular, parecia-me formoso. De origem inglesa, tinha os cabelos castanhos entremeados de louro, uma alteração exótica na pronúncia, olhos azuis 


\section{Sílvio José Benelli}

de estrias cinzentas, oblíquos, pálpebras negligentes, quase a fechar, que se rasgavam, entretanto, a momentos de conversa, em desenho gracioso e largo. (p. 170)

Vizinhos de dormitório, eu, deitado, esperava que ele dormisse para vê-lo dormir e acordava mais cedo para vê-lo acordar. Tudo que nos pertencia, era comum. Eu por mim positivamente adorava-o e o julgava perfeito. Era elegante, destro, trabalhador, generoso. Eu admirava-o, desde o coração até a cor da pele e à correção das formas. Nadava como as toninhas. A água azul fugia-lhe diante em marulho, ou subia-lhe aos ombros, banhando de lustre de marfim polido a brancura do corpo. Dizia as lições com calma, dificilmente às vezes, embarcado por aspirações ansiosas de asfixia. Eu mais o prezava nos acessos doentios da angústia. Sonhava que ele tinha morrido, que deixara bruscamente o Ateneu; o sonho despertava-me em susto, e eu, com alívio, avistava-o tranqüilo, na cama próxima, uma das mãos sob a face, compassando a respiração ciciante. No recreio, éramos inseparáveis, complementares como duas condições recíprocas de existência. Eu lamentava que uma ocorrência terrível não viesse de qualquer modo ameaçar o amigo, para fazer valer a coragem do sacrifício, trocar-me por ele no perigo. Vinham-me reminiscências dos exemplos históricos de amizade; a comparação pagava bem. (Pompéia, 1888/1997, p. 170)

No campo dos exercícios, à tarde, passeávamos juntos, voltas sem fim, em palestra sem assunto, por frases soltas, estações de borboletas sobre as doçuras de um bemestar mútuo, inexprimível. Falávamos baixo, bondosamente, como temendo espantar com a entonação mais alta, mais áspera, o favor de um gênio benigno que estendia sobre nós a amplidão invisível das asas. Amor unus erat. (pp. 170-171)

Entrávamos pelo gramal. Como ia longe o burburinho de alegria vulgar dos companheiros! Nós dois sós! Sentávamos à relva. Eu descansando a cabeça aos joelhos dele, ou ele nos meus. Calados, arrancávamos espiguilhas à grama. $\mathrm{O}$ prato era imenso, os extremos escapavam já na primeira solução de crepúsculo. Olhávamos para cima, para o céu. Que céu. Que céus de transparência e de luz! Ao alto, ao alto, demorava-se ainda, em cauda de ouro, uma lembrança do sol. A cúpula funda descortinava-se para as montanhas, diluição vasta, tenuíssima de arco-íris. Brandos reflexos de chama, depois, o belo azul de pano, depois a degeneração dos matizes para a melancolia noturna, prenunciada pela última zona de roxo doloroso. Quem nos dera ser aquelas aves, duas, que avistávamos na altura, amigas, declinando feliz a luz, em pleno dia ainda, quando na terra iam por tudo as sombras! (p. 171) 
Os dois amigos liam muito em companhia, a solidão de Robinson Crusoé, a solidão e o sentimento de Paulo e Vírginia, enlevavam-se com a pastoral de Bernardin de Saint- Pierre, esboçaram poesias e romances ambientados na Idade Média.

Quando Sérgio ouviu o nome do amigo citado no "processo do caso Cândida", investigação institucional de uma ocorrência de homossexualismo entre os alunos (p. 160), sofreu em silêncio o golpe e desesperou-se por não encontrar um meio de partilhar com Egbert a vergonha. Quando tudo passou e Egbert não sofreu maiores sanções, Sérgio reencontrou-o e não comentaram nem uma vez sequer o desagradável incidente, manifestando assim a solidariedade entre os internados (p. 173).

Declamavam juntos o teatro clássico:

Um era Augusto, outro Cina; um Nearco, outro Poliúto; um Horácio, outro Curiácio, D. Diogo e o Cid, Joas e Joad, Nero e Burro, Filinto e Alceste, Tartufo e Cleanto. O arvoredo era um cenário deveras. Dialogávamos, com toda a força das encarnações dramáticas, a gravura cavalheiresca, o civismo romano, as apreensões de rei ameaçado, o heroísmo da fé, os arrufos da misantropia, as sinuosidades do hipócrita. Uma estátua de deusa anônima, de louça esfolada, verde de velhice, constituía o auditório, auditório atento fixamente, comedido, sem demasias de aplausos nem reprovação, mas constante e infatigável. (Pompéia, 1888/1997, p. 175)

Para o desempenho de papéis femininos havia dificuldades; cada um queria a parte mais enérgica do recitativo. Tirava-se a sorte, e, segundo o acaso, um de nós ou o outro enfiava sem cerimônia as saias de qualquer dama e ia perfeita a toilette do sentimento; noivado de Chimène, desespero de Camila, luto de Paulina, ambição de Agripina, soberania de Ester, astúcia de Elmira, dubiedade de Celimene. Outro papel custoso de distribuir era o de Burro, papel honesto, entretanto, e altamente simpático. Ninguém o queria fazer, o virtuoso conselheiro de Nero. (p. 175)

Neste idílio ia a amizade de Sérgio e Egbert, até que ambos foram premiados com um jantar na casa do diretor, por terem se distinguido nos estudos. No jantar, Sérgio fica deslumbrado com Ema, a esposa de Aristarco:

Uma atenção absorveu-me exclusiva e única. D. Ema reconheceu-me: era aquele pequeno das madeixas compridas! Conversou muito comigo. Um fiapo branco 
pousava-me ao ombro do uniforme; a boa senhora tomou-o finamente entre os dedos, soltou-o e mostrou-me, sorrindo, o fio levíssimo a cair lentamente no ar calmo... Estava desenvolvido! Que diferença do que era há dois anos!... Miragem sedutora de branco, fartos cabelos negros colhidos para o alto com infinita graça, uma rosa nos cabelos, vermelha como são vermelhos os lábios e os corações, vermelha como um grito de triunfo. Nada mais. Ramalhetes à mesa, um caldo ardente, e sempre a obsessão adorável do branco e a rosa vermelha. Estava a meu lado, pertinho, deslumbrante, o vestuário de neve. Servia-me alguns pratos, muitas carícias; eu devorava as carícias. Não ousava erguer a vista. Uma vez ensaiei. Havia sobre mim dois olhos perturbadores, vertendo a noite... (p. 176)

Quando retornou ao Ateneu, Sérgio encontrava-se transformado: "De volta ao Ateneu, senti-me grande. Crescia-me o peito indefinivelmente, como se me estivesse a fazer homem por dilatação" (Pompéia, 1888/1997, p. 176). A paixão por Ema modificou seu relacionamento com Egbert: "...olhava agora para Egbert como para uma recordação e para o dia de ontem. Daí começou a esfriar o entusiasmo de nossa fraternidade” (p. 177).

Sérgio sonhava com sua amada (p. 181):

Que outra criatura era eu ao despertar! A aparição encantadora extinta; mas eu sofria da reação das trevas que sucede aos deslumbramentos. Continuava cordialmente com o Egbert. Parecia-me, entretanto, a sua amizade agora uma coisa insuficiente como se houvesse em mim uma selvageria amordaçada de afetos. Egbert parecia às vezes um intruso. Passeando com ele, que diferença de outrora! Produzia-me o efeito de uma terceira pessoa. Eu preferia andar só. (pp. 181-182)

Sérgio foi submetido a novos exames escolares e promovido (pp. 177181). Também foi transferido para o dormitório dos maiores. "Esta mudança distanciava-me ainda mais do Egbert; passamos a nos encontrar somente à tarde, no campo" (p. 182).

Nesta nova fase, Sérgio pouco se ocupava dos estudos e passava o tempo deitado preguiçosamente, manifestando, aí, sua estratégia adaptativa e ajustamento secundário: "Depois das aulas, subia para o dormitório, aproveitando-me do relaxamento da polícia do salão. O inspetor responsável era o Silvino. Receoso de uma represália dos grandes, o prudente bedel deixava andar" (p. 182). Com os internados maiores, a vigilância era obrigada a fazer 
concessões, medindo forças e usando de maior prudência, para evitar uma agressão que revidasse uma repressão exagerada.

Eu me deitava preguiçoso, ouvindo a grita do pátio, como coisa absolutamente alheia à minha vida. Contava as tábuas do teto, porção de traços paralelos que se perdiam num reflexo de tinta. Às vezes lia narrativas de Dumas, que não distraíam. Em outras camas, deitados como eu, de cara para cima, cruzando os botins, alguns colegas fumavam, soprando, devagarinho, colunas de fumo que subiam, verticalmente, e rodavam azuis. A um canto, no fim do salão, jogavam três parceiros, bocejantes, acentuando sem entusiasmo as alternativas do azar como uma partida de sonâmbulos. Muitas vezes na modorra pesada da sesta, as costas aquecidas da posição, fechando-me os olhos, ao brilho do sol que adivinhava lá fora no terreiro abrasado, eu adormecia. À hora da aula ou do jantar, um companheiro puxava-me. (p. 182)

Estes intervalos de dormência sem sonho, sem idéias, sem definida cisma, eram o meu sossego. Pensar era impacientar-me. Que desejava eu? Sempre o desespero da reclusão colegial e da idade. Vinham-me crises nervosas de movimento, e eu cruzava de passos frenéticos o pátio, sôfrego, acelerando-me cada vez mais, como se quisesse passar adiante do tempo. Nem me interessavam as intrigas do salão. Eque intrigas! Exatamente a substância do afamado mistério do chalé (p. 182), dormitório coletivo dos maiores, objeto de ambição curiosa dos menores do internato.

Podemos observar uma espécie de moratória à qual o adolescente internado num colégio está submetido: seu aborrecimento, tédio, falta de sentido, desejo de que o tempo passe depressa e que ele cresça, para finalmente ser livre, adulto, capaz de exercer-se na vida.

\section{Epílogo: a emergência do feminino na vida de Sérgio}

Depois da "solenidade da distribuição bienal dos prêmios" (Pompéia, 1888/1997, pp. 193-204), Sérgio caiu doente:

Logo depois da festa de educação física, que foi alguns dias depois da grande solenidade dos prêmios, eu adoecera. Sarampos, sem mais nem menos. Por motivo dos seus padecimentos, meu pai seguira para a Europa, levando a família. Eu ficara no Ateneu, confiado ao diretor, como a um correspondente. (p. 207) 


\section{Sílvio José Benelli}

Meia dúzia de rapazes eram meus companheiros. Que terrível soledade o Ateneu deserto. No pátio, o silêncio dormia ao sol, como um lagarto. Vagávamos, bocejando pelas salas desmontadas, despidas; as carteiras amontoadas num canto, na caliça os pregos somente das cartas com alguns quadros restantes de máximas, por maior insipidez, os mais teimosos conselhos morais. Nos dormitórios, as camas desfeitas mostravam o esqueleto de ferro pintado, o xadrez das chapas cruzadas. Principiava um serviço vasto de lavagem, envernizagem, caiação; vieram pintores reformar os aspectos do edifício que se renovavam todos os anos. Os tristes reclusos das férias, ficávamos, no meio daquela restauração geral, como coisas antigas, do outro ano, como o deplorável inconveniente de se não poder caiar de novo e pintar. (pp. 207-208)

\section{Sérgio sentiu-se fisicamente mal.}

Assim passei alguns dias sem me queixar. Certa manhã, descubro no corpo um formigamento de pintinhas rubras. Aristarco fez-me recolher na enfermaria, um prolongamento de sua residência para os lados da natação. Veio o médico, o mesmo do Franco; não me matou. D. Ema foi para mim o verdadeiro socorro. Sabia tanto zelar, animar, acariciar, que a própria agonia aos cuidados do seu trato fora uma ressurreição. (Pompéia, 1888/1997, p. 208)

Sérgio ficou recluso na enfermaria enquanto se recuperava da doença, sob os cuidados maternais de Ema e seu amor por ela floresceu com intensidade:

A convivência cotidiana na solidão do aposento estabelecera a entranhada familiaridade dos casais. Ema afetava não ter mais para mim avarezas de colchete. "Sérgio, meu filhinho.” Dava-se os bons dias. Saía, voltava fresca, com o grande, vernal sorriso rorejado ainda do orvalho das ablusões. Rindo sem causa: da claridade feliz da manhã, de me ver forte, quase bom. Debruçava-se expansiva, resplendendo a formosura sobre mim, na gola do peignoir, como um derramamento de flores de uma cornucópia. Tomava-se a fronte nas mãos, colava à dela; arredava-se um pouco e olhava-me de perto, bem dentro dos olhos, num encontro inebriante de olhares. Aproximava o rosto e contava, lábios sobre lábios, mimosas historietas sem texto, em que falava mais a vivacidade sanguínea da boca, do que a imperceptível confusão dos arrulhos cantando-se na garganta como um colar sonoro. Achava-me pequenino, pequenino. Sentava-se à cadeira. Tomava-me ao colo, acalentava-me, agitava-me contra o seio como um recém-nascido, inundando-me de irradiações quentes de maternidade, de amor. Desprendia os cabelos e com um ligeiro movimento de espáduas fazia cair sobre mim uma tenda escura. De cima, sobre as faces, 


\section{Produção de Subjetividade no "Ateneu"}

chegava-me o bafejo tépido da respiração. Eu via, ao fundo da tenda, incerto como em sonhos, a fulguração sideral de dois olhos. (p. 212)

Sérgio convalesceu neste romance platônico com sua enfermeira. Mas "tudo acabou com um fim brusco de mau romance" (p. 213). O Ateneu ardeu em chamas e foi consumido num incêndio. $\mathrm{O}$ autor do sinistro foi Américo, um aluno internado no Ateneu à própria revelia pelo pai:

Entre os reclusos das férias, contava-se um rapaz, matriculado de pouco, o Américo. Vinha da roça. Mostrou-se contrariado desde o primeiro dia. Aristarco tentou abrandá-lo; impossível: cada vez mais enfezado. Não falava a ninguém. Era crescido e parecia de robustez não comum. Olhavam para ele como para uma fera respeitável. De repente desapareceu. Passado algum tempo vieram três pessoas reconduzindo-o: o pai, um correspondente e um criado. O rapaz amarelo, com manchas vermelhas, movediças, no rosto, mordia os beiços até ferir. O pai pediu contra ele toda a severidade. Aristarco, que tinha veleidades de amansador, gloriando-se de saber combinar irresistivelmente a energia com o modo amoroso, tranqüilizou o fazendeiro: "Tenho visto piores". Carregando a vista com toda a intensidade da força moral, segurou o discípulo rijamente pelo braço e fê-lo sentar-se. "Tu ficarás, meu filho!" O moço limitou-se a responder, cabisbaixo, possuído de repentina complacência: "Eu fico". Dizem que o pai o tratara terrivelmente, vendo-o apresentar-se em casa, evadido. Com a proximidade da festa dos prêmios o caso do desertor ficou esquecido, e ninguém jamais foi como ele exemplo de cordura. (p. 213)

O fogo devorou o colégio. "O incêndio fora propositalmente lançado pelo Américo, que para isso rompera o encanamento do gás no saguão das bacias. Desaparecera depois do atentado" (p. 217). Impossível não ver no gesto do incendiário uma semelhança com o que acontece atualmente nas revoltas em presídios e instituições de internamento para adolescentes infratores, que incendeiam colchões e pavilhões inteiros, rebelando-se contra condições desumanas de vida.

Por outro lado, esse desfecho trágico da história também nos faz pensar na vingança de Pompéia contra sua longa e árdua experiência no colégio interno: ao escrever suas memórias, pôde acertar as contas com o passado, e tal como os internos de hoje aos quais aludimos acima, ateou fogo ao Ateneu, revoltado com sua condição de adolescente internado. 
"Desaparecera igualmente durante o incêndio a senhora do diretor" (p. 217). Golpe de misericórdia infligido no poderoso Aristarco?

Lá estava Aristarco, tresnoitado, o infeliz... Lá estava, a uma cadeira em que passara a noite, imóvel, absorto, sujo de cinza como um penitente, o pé direito sobre um monte de carvões, o cotovelo espetado na perna, a grande mão felpuda envolvendo o queixo, os dedos perdidos no bigode branco, sobrolho carregado (...) Ele, como um deus caipora, triste, sobre o desastre universal de sua obra. (pp. 217-218)

Aqui Pompéia/Sérgio interrompe sua "crônica das saudades" (p. 218).

Em seu percurso pelo internato escolar, Sérgio foi confrontando a vida mesma em sua multiplicidade: amores, ódios, rixas, rivalidades, orgulho, vaidade, posições femininas, masculinas, o menino tornourse um homem. $\mathrm{O}$ menino pode sair do "Ateneu", mas parece que foi difícil o "Ateneu" sair do menino. Talvez Raul Pompéia tenha produzido "O Ateneu" para apropriarse de sua dolorosa formação escolar e existencial. Inclusive, podemos também pensar num forte processo de institucionalização, pois, de acordo com Goffman (1961/1987), a internação prolongada produz maior resistência a deixar o estabelecimento de reclusão. Ter vivido tal experiência constitui um sujeito, sua história faz dele o que é hoje. Pompéia parece orbitar o internato onde viveu como seu "grande sintoma". É semelhante ao ex-usuário de drogas, que, inclusive em abstinência voluntária, permanece orbitando-as, mesmo que seja trabalhando em uma clínica que se ocupa com usuários. De qualquer modo, o objeto permanece central na sua vida.

\section{Atravessamentos das instituições totais e as funções do internato escolar}

Há muitas semelhanças entre a prisão e o hospital psiquiátrico que são indicadas por Goffman (1961/1987) e Levinson e Gallagher (1964/1971). Essa semelhança aumenta se considerarmos que a prisão não evoluiu historicamente como as instituições médicas (Foucault, 1975/1999b). As principais tarefas desempenhadas pelos funcionários (equipe dirigente) desse estabelecimento diferem de modo superficial das empreendidas pelas equipes 
dos hospitais psiquiátricos. Entretanto, os critérios oficiais que orientam a política institucional do presídio são distintos.

No paralelo que podemos estabelecer entre os fins educativos do internato escolar e os objetivos terapêuticos-correcionais do hospital psiquiátrico e da prisão, existe mais do que uma simples analogia. As três organizações procuram, de modos que variam tanto entre si quanto dentro de cada uma, promover o desenvolvimento pessoal e os conhecimentos sobre o caráter, o conceito sobre si mesmo, a competência e os recursos psicossociais que significarão uma diferença na vida dos membros residentes depois da sua graduação. Podemos falar em uma "terapeutização" da Pedagogia e uma "pedagogização" da terapia.

A função de custódia corresponde em graus semelhantes. Como membro da comunidade escolar, o estudante depende em grande medida do que o colégio lhe proporciona quanto ao seu bem-estar, alojamento, recreação, saúde etc. Ele também está bastante sujeito ao sistema de autoridade e controle institucional (normas sobre a admissão, expulsão, regulamentos, aproveitamento acadêmico, comunitário e condições de graduação).

As funções de reclusão podem ser menos proeminentes, pois ninguém se torna aluno em regime de internato por mandato judicial. Mesmo assim, alguns alunos podem sentir o colégio como um ambiente carcerário e restritivo, ao qual foram entregues por seus pais. As concepções do estudante que vive num internato escolar, de Hesse (1970, 1980); Lautréamont (1986); Musil (1906/1986); Perrone-Moisés (1988); Pompéia (1888/1997); Rego (1933/1979) e Trevisan (1985) têm muito em comum com a apresentada sobre o paciente como internado.

Há uma série de questões que são comuns ao internado no colégio e no hospital psiquiátrico. Ambos constróem sistemas de princípios racionais ideológicos que definem o bom internado e o bom estabelecimento. Avaliam a instituição em termos ideológicos e quanto ao significado emocional pessoal que tem para eles. Devem decidir o que ocorre em suas pessoas, um com relação ao processo formativo (conhecimentos, capacidade de ocupação, características de sua personalidade) que lhe é oferecido e, o outro, 
quanto aos seus problemas psiquiátricos; entre o que são agora e o que querem chegar a ser. Assim como as dificuldades e os sentimentos do paciente o motivam para o trabalho terapêutico, o estudante é estimulado pela sensação de ignorância e imaturidade a participar do processo educativo. $\mathrm{O}$ conhecimento das próprias limitações e o desejo de mudanças interiores servem de estímulo para esforços educativos e terapêuticos na medida em que são acompanhados pela percepção do próprio valor pessoal e de um ambiente que valorize e possibilite esse esforço.

A vida pessoal do estudante dentro do estabelecimento, tanto m dormitório quanto em outras partes, tem um grande significado para seu desenvolvimento, além de sua importância para atingir os fins educativos mais concretos. Isso é semelhante ao que se passa entre os membros internados numa instituição psiquiátrica. $\mathrm{O}$ estudante responde muito à cultura geral de seus pares e às alianças e rupturas transitórias que se produzem dentro do corpo estudantil, com os professores e com a administração. A relação entre os estudantes, ainda que menos ameaçadora do que a que existe entre pacientes, costuma ter aspectos problemáticos que causam ansiedade. $\mathrm{O}$ estudante pode se sentir menos ameaçado pelos problemas mentais de seus colegas (embora isso também possa acontecer), mas ainda tem motivos para se preocupar com eles. Surgem questões relativas ao desempenho acadêmico, rivalidades, invejas, temores, medo do fracasso, disputas, competição por reconhecimento etc.

Diferentemente do paciente internado, um estudante de colégio interno sente orgulho por pertencer a um colégio, como resultado de esforços anteriores e como meio de obter conquistas vitais. $\mathrm{O}$ estudante não perde totalmente seus direitos civis de cidadão e o tempo de sua permanência geralmente está fixado de modo claramente delimitado.

A participação na vida colegial do internado pode ser não apenas uma oportunidade, mas também motivada pela pressão dos pais, professores, pares e outros. Os aspectos coercitivos da vida no internato escolar, ainda que menos explícitos e brutais do que os do hospital psiquiátrico, também podem ser mais massificantes e difíceis de se enfrentar. Existem as possibi- 
lidades vergonhosas do fracasso acadêmico, da incapacidade intelectual e da mudança, que pode ser muita ou pouca, antes da formatura.

\section{Conclusão}

Entendemos que o Ateneu, como estabelecimento, constitui-se num bloco de condições materiais objetivas (sua organização espacial, o regulamento meticuloso que rege sua vida interior, as várias atividades aí desenvolvidas, os diversos personagens que aí vivem e se encontram, cada um com uma função, um lugar etc.), bem como de relações de comunicação e de poder, produtoras de uma subjetividade específica.

Acreditamos que a atividade que assegura o aprendizado e a aquisição de aptidões ou tipos de comportamento aí se desenvolve através de todo um conjunto de comunicações reguladas (aulas, perguntas e respostas, ordens, exortações, signos codificados de obediência, marcas distintivas do valor de cada um e dos níveis de saber) e através de uma série de procedimentos de poder (enclausuramento, vigilância, recompensa e punição, hierarquia piramidal). Como todo espaço institucional fechado, o internato parece funcionar a partir de dois elementos essenciais: o aparelho, constituído pelo próprio estabelecimento, e regras (explícitas e implícitas).

Em termos de efeitos éticos, a experiência de internação numa instit uição total produz resultados muito distantes dos objetivos oficiais que costumam constar em seus estatutos e regimentos. Ela parece normalmente produzir efeitos contrários aos prometidos. As instituições totais tendem a ser (re)produtoras de indivíduos normalizados, modelados numa subjetividade capitalística (Guattari, 1992). A lógica da instituição totalitária despoja o indivíduo de sua autonomia, responsabilidade, capacidade de reflexão crítica, procurando transformá-lo em massa dócil, modelável, obediente e submissa.

O Ateneu é também um estabelecimento que utiliza mecanismos aparentemente repressivos para controlar a sexualidade dos internados, mas o 
que realmente parece fazer é incitá-la, acabando por fomentá-la ao proibi-la. Ao encerrar os estudantes como um grupo monossexuado no claustro totalitário, acaba por vê-lo emergir perverso e polimorfo.

Sobre sexo, há um enorme silêncio oficial. Há apenas as proibições do regimento indicando as penas para a "imoralidade". Porém, se sobre isso não se fala, "isso" fala, numa intensificação dos afetos e dos corpos, num intenso erotismo que, passando pelo flerte e paquera, se configura eventualmente em relacionamentos, em "casos", em prováveis namoros, na formação de casais apaixonados, em amores secretos, nem sempre discretos, platônicos ou intensamente carnais. Assim sendo, dentro dos muros do internato, sob o interdito sexual, encontramos o frescor do desejo e uma sexualidade fervilhante. Os rapazes podem experimentar diversas práticas amorosas. Parece que a vida no claustro tende a produzir uma exacerbação, intensificação e passagens ao ato das possibilidades neuróticas e perversas dos jovens estudantes.

$\mathrm{Na}$ sociedade capitalista, as instituições metabolizam a contradição principal (capital/trabalho) através de diversas estratégias. As relações de poder são escamoteadas e interpretadas de um modo funcionalista: tendência a uma psicologização interiorizante e individualizante, ou a uma sociologização que universaliza os interesses da equipe dirigente (representante das forças hegemônicas sociais e institucionais), negação das contradições sociais reais e um processo de naturalização que elude a historicidade dos fatos (Albuquerque, 1980).

Acreditamos que é necessário pensar as relações de poder situadas no conjunto de práticas sociais que produzem os sujeitos como corpos dóceis, adestrados e seres desejantes (Foucault, 1975/1999b). Uma articulação pertinente dos fenômenos emergentes no contexto institucional pode ser elaborada num processo de análise institucional, procurando superar posicionamentos funcionalistas ingênuos.

Pensamos que as dificuldades e problemas das instituições totais não se modificariam apenas com novos métodos e técnicas de gerenciamento institucional. A inércia do instituído tende a mover os atores institucionais 
na direção de receitas que prometam soluções mágicas e rápidas para seus impasses e conflitos. Assim, buscam-se reformas para manter tudo como está, produzindo modificações em aspectos secundários que geram somente efeitos paliativos (Baremblitt, 1998).

Seria preciso ousadia para modificar o eixo central das discussões: teríamos de problematizar o objeto institucional das diversas instituições totais, desnaturalizando, "despsicologizando", "dessociologizando" o homem que aí é processado, tomando-o como um sujeito infinitamente mais complexo e multifacetado do que a caricatura empobrecida que faz dele um personagem habitante do universo institucional totalitário.

Consideramos que é necessário analisar as diversas práticas institucionais (formativas, educativas, pedagógicas, terapêuticas, correcionais, sócioeducativas), problematizando seus pressupostos subjacentes, procurando detectar como e até que ponto tais ações funcionam como filtros de transformação seletiva e deformante de qualquer proposta inovadora.

Trata-se mesmo de promover uma revolução conceitual: dependendo de como vemos determinado objeto, partimos da consideração de sua suposta natureza essencial para a produção de saberes e técnicas para trabalhá-lo. Os meios e os fins seriam então decorrentes dessa natureza presumida do objeto. É por isso que acreditamos na importância de uma análise das práticas, daquilo que fazemos no contexto institucional. O fazer embute em si uma teoria, um objeto, saberes e técnicas: produz subjetividade, modos de existência, sujeitos, universos de materialidade social. Tal processo pode se submeter ao sentido do processo hegemônico de produção de subjetividade, mas também pode orientar-se no sentido de produções singularizadas.

Benelli, S. J. (2003). The boarding school "O Ateneu": Subjectivity production into total institution. Psicologia USP, 14(3), 133-170.

Abstract: We tried to detect the effects of institutionalization on the subjectivity production from a total school enviroment. The study case is the novel "O Ateneu", by Raul Pompéia, which we have analyzed using 


\section{Sílvio José Benelli}

Goffman's theory related to total institutions. We have described the moral career which the character Sérgio develops by going to a boarding school, whereby the vicissitudes were mapped into that environment: period of adaptation, evolutive crises, sexual initiation, problems of brotherly rivalry, etc. Total institutions seem to be organized from a particular way and works autonomously. We could only understand the social problems and the effects of subjectivity produced by total institutions, using the studies of power relations underlying those milieus. The absent time that the individual is enclosed as an inmate can place deep marks into his/her subjectivity and turn into an appropriate case of study in itself.

Index terms: Subjectivity. Institutional analysis. Boarding school. Education.

Benelli, S. J. (2003). L'internat scolaire «O Ateneu »: production de subjectivité dans l'institution totale. Psicologia USP, 14(3), 133-170.

Résumé: Dans cet article on cherche à identifier les effets de l'institutionnalisation dans la production de la subjectivité dans un établissement scolaire total. La recherche est basée sur le roman «O Ateneu » de Raul Pompeia, analysé à partir de la théorie de Goffman (1961-1987) relative aux institutions totales. On décrit l'itinéraire moral que le personnage Sergio développe, à son entrée à l'internat, évoquant les vicissitudes par lesquelles il passe dans ce contexte institutionnel : période d'adaptation, crises évolutives, initiations sexuelles, problèmes de rivalités, etc. les établissements totaux semblent s'organiser d'une façon caractéristique et fonctionner de manière autonome. On pourra comprendre les problèmes sociaux et les effets sur la subjectivité produite par les institutions totales par l'étude des relations de pouvoir subjacentes à ces types d'établissements. Le temps pendant lequel un individu vit comme interné peut laisser des marques profondes dans sa subjectivité et se configure comme un thème personnel approprié.

Mots-cles: Subjectivité. Analyse institutionnelle. Internat. Éducation. 


\section{Produção de Subjetividade no "Ateneu"}

\section{Referências}

Albuquerque, J. A. G. (1980). Instituição e poder: A análise concreta das relações de poder nas instituições. Rio de Janeiro: Graal.

Baremblitt, G. F. (1998). Compêndio de análise institucional e outras correntes: Teoria e prática (4a ed.). Rio de Janeiro: Record/Rosa dos Tempos.

Benelli, S. J. (2002). O internato escolar como instituição total: Violência e subjetividade. Psicologia em Estudo, 7(2), 19-29.

Benelli, S. J., \& Costa-Rosa, A. (2002). A produção da subjetividade no contexto institucional de um Seminário Católico. Estudos de Psicologia, 19(2), 37-58.

Cabras, A. (1982). Os anjos querem ser homens - Um estudo sobre a laicização de padres no Brasil. Dissertação de mestrado, Faculdade de Filosofia, Letras e Ciências Humanas, Universidade de São Paulo, São Paulo.

Castel, R. (1978). A ordem psiquiátrica: A idade de ouro do alienismo (M. T. C. Albuquerque, trad.). Rio de Janeiro: Graal.

Cruz, S. G. F. P. (1989). Herói ou bandido? Um estudo sobre a produção de identidade em policiais militares. Dissertação de mestrado, Pontifícia Universidade Católica de São Paulo, São Paulo.

Ferraz e Ferraz, M. G. C. (1994). Religare. Uma cartografia da fé (Vols. 1-2). Tese de doutorado, Pontifícia Universidade Católica de São Paulo, São Paulo.

Foucault, M. (1999a). História da loucura na Idade Clássica (6a ed.). São Paulo: Perspectiva. (Trabalho original public ado em 1972)

Foucault, M. (1999b). Vigiar e punir: Nascimento da prisão (21a ed., R. Ramalhete, trad.). Petrópolis, RJ: Vozes. (Trabalho original publicado em 1975)

Goffman, E. (1987). Manicômios, prisões e conventos (2a ed., D. M. Leite, trad.). São Paulo: Perspectiva. (Trabalho original publicado em 1961)

Guattari, F. (1992). Heterogênese. In F. Guattari, Caosmose: Um novo paradigma estético (A. L. Oliveira, trad.). Rio de Janeiro: Ed. 34.

Guirado, M. (1986). Instituição e relações afetivas: O vínculo com o abandono. São Paulo: Summus.

Guirado, M. (1987). Psicologia institucional. São Paulo: EPU.

Hesse, H. (1970). Narciso e Goldmund (4a ed., M. M. Spiritus, trad.). São Paulo: Brasiliense.

Hesse, H. (1980). Menino prodígio (5a ed., A. Cabral, trad.). Rio de Janeiro: Record. 


\section{Sílvio José Benelli}

Lautréamont, C. (1986). Cantos de Maldoror (C. Willer, trad.) São Paulo: Max Limonad.

Levinson, D. J., \& Gallagher, E. B. (1971). Sociología del enfermo mental. Buenos Aires, Argentina: Amorrortu. (Trabalho original publicado em 1964)

Musil, R. (1986). O jovem Törless (L. Luft, trad.). Rio de Janeiro: Rio Gráfica. (Trabalho original publicado em 1906)

Perrone-Moisés, L. (Org.). (1988). O Ateneu: Retórica e paixão. São Paulo: Brasiliense.

Pompéia, R. (1997). O Ateneu. São Paulo: Publifolha. (trabalho original publicado em 1888)

Rego, J. L. (1979). Doidinho (18a ed.). Rio de Janeiro: José Olympio. (Trabalho original publicado em 1933)

Rocha, C. L. R. (1991). Muitos são os chamados mas poucos escolhidos: Um estudo sobre a vocação sacerdotal. Dissertação de mestrado, Instituto de Filosofia, Letras e Ciências Humanas, Universidade Estadual de Campinas, Campinas, SP.

Salla, F. (2000). A retomada do encarceramento: As masmorras high-tech e a atualidade do pensamento de Michel Foucault. In F. Biroli \& M. C. Alvarez (Orgs.), Cadernos da F.F.C. - UNESP. Marília, SP: Unesp Publicações.

Tagliavini, J. V. (1990). Garotos no túnel: Um estudo sobre a imposição da vocação sacerdotal e o processo de condicionamento nos seminários. Dissertação de mestrado, Instituto de Filosofia, Letras e Ciências Humanas, Universidade Estadual de Campinas, Campinas, SP.

Trevisan, J. S. (1985). Em nome do desejo (2a ed.). São Paulo: Max Limonad. 